\title{
MORTALITY ANALYSIS OF THE PATIENTS WITH ALCOHOLIC LIVER CIRRHOSIS
}

\author{
N.R. Matkovska \\ IVANO-FRANKIVSK NATIONAL MEDICAL UNIVERSITY, IVANO-FRANKIVSK, UKRAINE
}

Background. Alcohol is considered to be the main risk factor for adverse event deaths around the world. In Ukraine, mortality due to alcoholic liver disease (ALD) has taken the second place in the structure of death causes from diseases of the digestive system.

Objective. The aim of the research was to study the peculiarities of the causes of death in the patients with alcoholic liver disease at the stage of liver cirrhosis (LC) based on the analysis of protocols of pathoanatomical research.

Methods. The analysis of 149 protocols of the pathoanatomical study of the patients, who died from alcoholic LC, has been carried out at the premises of the Pathoanatomical Department of the Ivano-Frankivsk Regional Clinical Hospital in 2006-2018.

Results. Most people were young and middle aged. Fatal cases were caused by decompensation of the LC with the development of hepatic, hepatic-renal, cardio-pulmonary insufficiency, pancreatic necrosis, gastrointestinal bleeding (GIB), sepsis, hepatocellular carcinoma (HCC). In $37.6 \%$ of the patients the concomitant illness was coronary heart disease (CHD), $10.7 \%$ of the people had hypertension. In $6 \%$ of the patients, ischemic stroke of the brain was diagnosed. In most people atherosclerotic vascular changes were revealed.

Conclusions. Excessive consumption of alcohol and, consequently, the development of $L C$, can be considered as an adverse factor in the reducing social standard of living. In the majority of people, who died from the decompensation of alcoholic $L C$, atherosclerotic vascular lesions have been detected. This indicates a significant prevalence of lipid metabolism disturbance in the people with alcoholic $L C$.

KEY WORDS: liver cirrhosis, alcoholic; cause of death; coronary disease; atherosclerosis.

\section{Introduction}

Demographic processes in Ukraine have signs of a protracted demographic crisis, which is closely related to the historical and socioeconomic peculiarities of the country's development. It is well-known that Ukraine belongs to countries with a progressive decline in demographic and reproductive potential, which leads to depopulation and population decline. At the beginning of 2016, the number of children in the population of Ukraine was $16.1 \%$, those of working age $-61.8 \%$, older than ablebodied - $22.1 \%$. The prevalence of women in the elderly as a result of higher mortality among males is the peculiarity of gender imbalance. Demographic aging, that is, the steady increase in the proportion of economically and socially inactive elderly people, combined with a decrease in the proportion of able-bodied people, has a direct impact on various spheres of life in the Ukrainian society $[1,2]$.

Corresponding author: Natalia R. Matkovska, Ivano-Frankivsk National Medical University,

16 Kropyvnytskyi str., Ivano-Frankivsk 76018

e-mail:nmail4you@gmail.com
Along with the aging of the population, the increase in the mortality rate, which is associated with endogenous diseases (circulatory and neoplastic diseases) and exogenous (respiratory diseases, digestive disorders, infectious and parasitic diseases, external) causes, is a topical issue. In recent years, much attention has been paid to the increase in the incidence of so-called non-infectious diseases, which is becoming a sign of not only an epidemic, but also a possible future pandemic $[3,4,5]$. According to the $\mathrm{WHO}$, 41 million people die from these diseases every year, accounting for $71 \%$ of all deaths in the world. Annually 15 million people between 30 and 69 years of age die from them. Cardiovascular diseases (stroke, heart attack) and malignant neoplasms are leading in prevalence and mortality among non-infectious diseases $[6,7]$.

Non-communicable diseases are the result of the combination of genetic, physiological, environmental and behavioural factors. Behavioural factors belong to the modified factors, and they can be changed. These include the use of tobacco, lack of physical activity, inappropriate nutrition, and alcohol abuse. The other not less 
important factors include metabolic factors: increased blood pressure, overweight/obesity, hyperglycemia, hyperlipidemia $[8,9,10]$.

Among non-infectious diseases caused by these risk factors, the digestive diseases together with the increase of the proportion of deaths are significant. Fibrosis and LC, alcohol and non-alcoholic liver diseases, which accounts for more than $50 \%$ of those who died of digestive diseases, contributed much to mortality from this class of deaths causes. The reasons for this are the continuous increase of quantitative and qualitative types of such patients, frequent chronic diseases, prolonged and severe courses, unfavourable consequences of a disease, prevailing affection of people of working age that is associated with medical and socio-economic factors $[11,12,13]$.

The main causes of liver damage are alcohol, viruses, non-alcoholic fatty liver disease. Alcohol is considered to be the main risk factor for adverse lethal outcomes around the world. Alcohol abuse is third among the causes of mortality among young people after tobacco and arterial hypertension and secondarily among the causes of liver transplantation in Europe. In Ukraine, mortality due to ALD takes the second place in the structure of causes of death from digestive diseases $[14,15,16]$.

The aim of the research was to study the peculiar features of the death causes in the patients with ALD at the stage of LC based on the analysis of protocols of pathoanatomical investigation.

\section{Methods}

The analysis of 149 protocols of pathoanatomical research of the patients, who died from alcoholic LC at the premicies of the Pathoanatomical Department of the IvanoFrankivsk Regional Clinical Hospital in 20062018 , was conducted. The average age of patients was $(56 \pm 12.1)$ years old (y. o.): women -
$(44.6 \pm 9.2)$ y. o., men - $(57.6 \pm 11.8)$ y. o., the average duration of the disease was $(6.6 \pm 1.8)$ years. The patients were divided into groups by age as follows: 44 young people (31 males and 13 females), 76 middle-aged persons (64 males, 12 females), 29 elderly patients (19 males, 10 females).

\section{Results}

According to the Child-Pugh criteria, among the patients with the LC, who died, there are 9 (6\%) persons with stage $A$ of the disease, 26 $(17.5 \%)$ - with stage B, 114 (76.5\%) persons with stage $C$. The causes of death in the patients with the LC of alcoholic etiology were pancreatic necrosis ( $4.7 \%$ of patients with stage A, $8.8 \%$ of patients with stage $B$ and $1.3 \%$ of patients with stage C), gastrointestinal bleeding (GIB) in $4 \%$ of patients with stage $B$ and in $36.3 \%$ of patients with stage $C$, liver failure - in $17.4 \%$ of patients with stage $C$, liver and kidney failure in $1.3 \%$ of people with stage B and in $10.7 \%$ of persons with stage $C$, sepsis - in $1.3 \%$ of patients with stage $B$ and in $6.7 \%$ of patients with stage $C$, cardio-pulmonary insufficiency in $1.3 \%$ of patients with stage $A$ and $2 \%$ of patients with stage B, HCC - in $4 \%$ of people with stage $C$ (Table 1).

According to the medical records, in all patients who died, the signs of portal hypertension, hepatosplenomegaly, cytolytic, hepatodepressive, mesenchymal-inflammatory syndrome were revealed. Among the manifestations of hepatic hyperazotemia there were hepatic encephalopathy and hepatopulmonary syndrome in all patients and hepatorenal syndrome - in $87.9 \%(3.4 \%, 10.7 \%, 4.7 \%$ of cases in young, middle aged and elderly patients), respectively. The signs of cholestasis syndrome were detected in $88.6 \%$ of patients.

Excessive subcutaneous fat was in $34.9 \%$ of cases, satisfactory - in $42.3 \%$, insufficient - in $22.8 \% .134$ (89.9\%) patients had ascites; 18.1

Table 1. Death causes in the patients with liver cirrhosis

\begin{tabular}{|c|c|c|c|c|c|c|}
\hline \multirow{3}{*}{ Death causes } & \multicolumn{6}{|c|}{ Stage of Child-Pugh criteria } \\
\hline & \multicolumn{2}{|c|}{$\begin{array}{c}A \\
(n=9)\end{array}$} & \multicolumn{2}{|c|}{$\begin{array}{c}B \\
(n=26)\end{array}$} & \multicolumn{2}{|c|}{$\begin{array}{c}C \\
(n=114)\end{array}$} \\
\hline & $\mathbf{n}$ & $\%$ & $\mathbf{n}$ & $\%$ & $\mathbf{n}$ & $\%$ \\
\hline Pancreatic necrosis & 7 & 4.7 & 13 & 8.8 & 2 & 1.3 \\
\hline Gastrointestinal bleeding & - & - & 6 & 4 & 54 & 36.3 \\
\hline Liver failure & - & - & - & - & 26 & 17.4 \\
\hline Liver and kidney failure & - & - & 2 & 1.3 & 16 & 10.7 \\
\hline Sepsis & - & - & 2 & 1.3 & 10 & 6.7 \\
\hline Cardio-pulmonary insufficiency & 2 & 1.3 & 3 & 2 & - & - \\
\hline Hepatocellular carcinoma & - & - & - & - & 6 & 4 \\
\hline
\end{tabular}


$\%$ of them suffered from ascites-peritonitis. Septicemic condition was revealed in $8.7 \%$ of cases and steatonecrosis of the omentum - in $16.1 \%$ of people. Hydrotorax was diagnosed in $83.2 \%$ of cases, hydropericardium - in all cases. Varicose of the oesophagus veins was diagnosed in all the lethal outcomes: of the $1^{\text {st }}$ stage - in $9.4 \%$ (14 persons), $2^{\text {nd }}$ stage - in $20.8 \%$ (31 persons), $3^{\text {rd }}$ stage - in $69.8 \%$ (104 persons) of cases, varicose veins of the stomach were present in $40.9 \%$ of cases. The bleeding from varicose veins of the oesophagus was in $57.7 \%$, a combination of bleeding from the veins of the oesophagus and the stomach - in $30.2 \%$ of cases. Depending on the age, the GIB was in $10.7 \%, 18.8 \%, 6.7 \%$ of the patients of young, middle and old age, respectively. Among men, GIB was revealed in $35.5 \%$ of young people, in $35.9 \%$ of middle-aged patients, in $15.4 \%$ of the elderly. Among women, GIB was revealed in $38.5 \%$ of young people, in $41.7 \%$ of middleaged patients and $30 \%$ of the elderly (Table 2 ).
Erosive gastroduodenitis was revealed in $66.4 \%$ (99 persons) of cases, acute ulcers of the duodenal bulb (DB) - in $10.7 \%$ (16 persons), acute ulcers of the stomach - in $2.7 \%$ (4 persons). The umbilical hernia was present in $12.7 \%$ of cases. Chronic hemorrhoids were diagnosed in $10.7 \%$ of people (with bleeding in $4.7 \%$ of cases).

Mild anemia was evidenced in $14.1 \%$ of patients, moderate - in $39.6 \%$, severe - in $49.7 \%$. In $86.6 \%$ of cases, the signs of chronic pancreatitis were revealed, $55 \%$ of patients had pancreatic lipodystrophy, $14.8 \%$ suffered from pancreatic necrosis (young and middle-aged persons), $7.4 \%$ had cholelithiasis, $61.7 \%$ - the signs of chronic cholecystitis, in $2 \%$ of people the signs of cholangitis were present. Hypotonia of the gall bladder was revealed in $12.1 \%$ of all cases.

Type 1 diabetes mellitus was diagnosed in $2 \%$ of young people, type 2 - in $4.7 \%$ of middleaged and elderly people. Chronic pyelonephritis

Table 2. The revealed pathoanatomical changes of internal organs depending on the liver cirrhosis decompensation stage

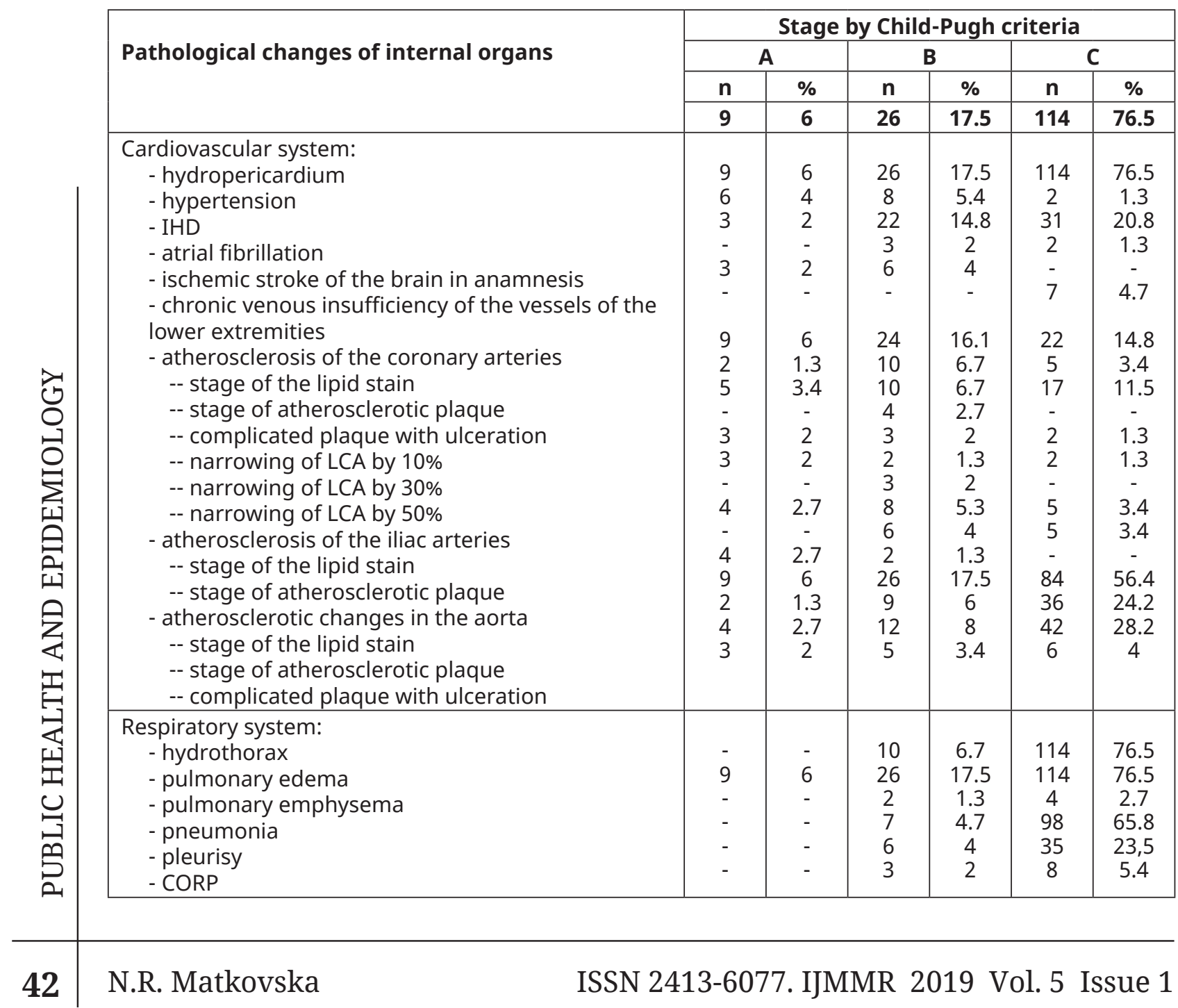




\begin{tabular}{|c|c|c|c|c|c|c|}
\hline \multirow{4}{*}{ Pathological changes of internal organs } & \multicolumn{6}{|c|}{ Stage by Child-Pugh criteria } \\
\hline & \multicolumn{2}{|c|}{ A } & \multicolumn{2}{|c|}{ B } & \multicolumn{2}{|c|}{ C } \\
\hline & $\mathbf{n}$ & $\%$ & $\mathbf{n}$ & $\%$ & $\mathbf{n}$ & $\%$ \\
\hline & 9 & 6 & 26 & 17.5 & 114 & 76.5 \\
\hline \multicolumn{7}{|l|}{ Digestive system: } \\
\hline - portal hypertension & 9 & 6 & 26 & 17.5 & 114 & 76.5 \\
\hline - cytolytic syndrome & 9 & 6 & 26 & 17.5 & 114 & 76.5 \\
\hline - hepatodepressive syndrome & 9 & 6 & 26 & 17.5 & 114 & 76.5 \\
\hline - mesenchymal-inflammatory syndrome & 9 & 6 & 26 & 17.5 & 114 & 76.5 \\
\hline - cholestasis syndrome & - & - & 18 & 12.1 & 114 & 87.9 \\
\hline - acrites & - & - & 20 & 13.4 & 114 & 86.6 \\
\hline & - & - & - & - & 27 & 18.1 \\
\hline $\begin{array}{l}\text { - ascites-peritonitis } \\
\text { - steatonecrosis of the omentum }\end{array}$ & - & - & - & - & 24 & 16.1 \\
\hline $\begin{array}{l}\text { - steatonecrosis of the omentum } \\
\text { - splenomegaly }\end{array}$ & 9 & 6 & 26 & 17.5 & 114 & 76.5 \\
\hline - umbilical hernia & $\overline{9}$ & $\overline{6}$ & 26 & 175 & 19 & 12.7 \\
\hline - varicose of the esophagus veins & 9 & 6 & 5 & 3,4 & & \\
\hline 1 -st degree & - & - & 21 & 14.1 & 10 & 6.7 \\
\hline 2-nd degree & - & - & - & - & 104 & 69.8 \\
\hline 3-d degree & - & - & - & - & 86 & 57.7 \\
\hline -- with bleeding & - & - & - & - & 61 & 40.9 \\
\hline - varicose veins of the stomach & - & 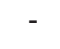 & & & 45 & 30.2 \\
\hline -- with bleeding & - & - & 8 & 5.3 & 91 & 61.1 \\
\hline - erosive gastroduodenitis & - & - & - & - & 16 & 10.7 \\
\hline - acute ulcers of the duodenal bulb & ـ & _ & 3 & 2 & $\begin{array}{c}4 \\
13\end{array}$ & 87 \\
\hline - acute ulcers of the stomach & - & - & & & 7 & 4.7 \\
\hline - chronic hemorrhoids & . & 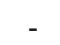 & 15 & 10.1 & 114 & 76.5 \\
\hline - hemorrhoidal bleeding & - & - & 6 & 4 & 76 & 51 \\
\hline - chronic pancreatitis & 10 & 6.7 & 8 & 5.4 & 4 & 2.7 \\
\hline - pancreatic lipodystrophy & 2 & 1.3 & 5 & 3.4 & 4 & 2.7 \\
\hline - pancreatic necrosis & - & - & 16 & 10.7 & 76 & 51 \\
\hline - cholelithiasis & - & - & - & - & 3 & 2 \\
\hline - chronic cholecystitis & - & - & - & - & 18 & 12.1 \\
\hline - cholangitis & - & - & j & 12 & 3 & $2^{2}$ \\
\hline - hypotonia of the gall bladder & & & & & & \\
\hline - type 1 diabetes mellitus & & & & & & \\
\hline - type 2 diabetes mellitus & & & & & & \\
\hline \multicolumn{7}{|l|}{ Urinary system: } \\
\hline - chronic pyelonephritis & - & - & 2 & 1.3 & 12 & 8.1 \\
\hline - kidney cyst & - & - & - & & 3 & 2 \\
\hline \multicolumn{7}{|l|}{ Nervous system: } \\
\hline - encephalopathy & 9 & 6 & 26 & 17.5 & 114 & 76.5 \\
\hline - alcoholic delirium in anamnesis & 7 & 4.7 & 4 & 2.7 & & - \\
\hline
\end{tabular}

was present in $9.4 \%$ of cases, kidney cyst in $2 \%$.

Pneumonia was diagnosed in $70.5 \%$, pleurisy - in $27.5 \%$, chronic obstructive pulmonary disease (COPD) - in $7.4 \%$, pulmonary emphysema - in $4 \%$. In $4.7 \%$, chronic venous insufficiency of the vessels of the lower extremities was revealed.

Among the concomitant diseases, hypertension was present in $10.7 \%$ of middle aged and elderly patients, ischemic heart disease (IHD) - in $37.6 \%$ of cases, $3.4 \%$ of these patients suffered from atrial fibrillation. $6 \%$ of patients had ischemic stroke of the brain in anamnesis, and $7.4 \%$ - alcoholic delirium. The signs of atherosclerosis were also evidenced. Particu- larly, the biochemical parameters of the lipid spectrum were characterized by an increase in the content of total cholesterol in the blood, low and very low-density lipoprotein cholesterol. Moreover, the degree of increase of these indicators was directly proportional to the degree of decompensation of LC.

Atherosclerotic changes in the aorta at the stage of lipid stain were present in $31.5 \%$ of cases, at the stage of atherosclerotic plaque - in $38.9 \%$, at the stage of complicated plaque with ulceration - in $9.4 \%$ of people. Atherosclerosis of the left coronary artery (LCA) was revealed in $11.4 \%$ at the lipid staining stage, at the stage of atherosclerotic plaque - in $21.5 \%$, ulcerated atherosclerotic plaque was present in $2.7 \%$. 
Narrowing of LCA by $10 \%$ was revealed in $5.3 \%$ of cases, by $30 \%-$ in $4.7 \%$, by $50 \%$ - in $2 \%$. Atherosclerosis of iliac arteries was present in $11.4 \%$ of patients.

\section{Discussion}

Consequently, analyzing clinical records of the pathoanatomical study of the patients with alcoholic LC, it was established that most patients were young and middle aged and died from decompensated LC with the development of multiple organ failure. In all cases, there was a lesion of the pancreas, in half of them lipodystrophy was revealed. Bleeding from varicose veins of the esophagus and stomach was the cause of death in $57.5 \%$ of people, $14.8 \%$ of patients died from pancreatic necrosis, $4 \%$ from HCC. IHD was the concomitant illness in $37.6 \%$ of the patients. More than $70 \%$ of the dead had atherosclerotic lesions of aorta, and one third of the persons had injured coronary vessels.

Excessive consumption of alcohol and, consequently, the development of LC, can be considered as an adverse factor in the reducing social standard of living. Fatal cases were caused by decompensation of LC, development of multiple organ failure, pancreatic necrosis, bleeding from the esophagus and stomach veins, HCC. Special attention should be paid to the combination of ALD with atherosclerotic vascular changes revealed in $79.8 \%$ of people, indicating a significant prevalence of lipid metabolism disorders among people with decompensated alcoholic LC.

Consequently, analyzing clinical records of the pathoanatomical study of the patients with alcoholic LC, it was established that most patients were young and middle aged and died from decompensated LC with the development of multiple organ failure. In all cases, a lesion of the pancreas was present, in half of them pancreatic lipodystrophy was revealed. The cause of death in $40.3 \%$ of people was bleeding from varicose veins of the esophagus and stomach with subcompensation and decompensation of LC, $17,4 \%$ of patients died from hepatic failure with decompensation of LC, 13.5 $\%$ of patients died from pancreatic necrosis with compensation and subcompensation of LC. Hepatic-renal failure was cause of death of the patients with subcompensation and decompensation of LC. Sepsis caused death of $8 \%$ of people with subcompensation and decom- pensation of LC, $4 \%$ of patients died from HCC. Cardio-pulmonary failure caused death in the patients with compensation and subcompensation of LC.

The cytolytic, hepato-depressive, mesenchymal-inflammatory, hepatic encephalopathy, cholestatic, hepatorenal, anemic, hepatopulmonary syndromes and portal hypertension were especially significant in the patient with subcompensation and decompensation of LC.

More than a third of people had overdeveloped subcutaneous fat. IHD was the concomitant illness in $37.6 \%$ of the patients. More than $70 \%$ of the dead had atherosclerotic lesions of aorta, and one third of the persons had injured coronary vessels.

Excessive consumption of alcohol and, consequently, the development of LC, can be considered as an adverse factor in the reducing social standard of living. Fatal cases were caused by decompensation of LC, development of multiple organ failure, pancreatic necrosis, bleeding from the esophagus and stomach veins, HCC. Special attention should be paid to the combination of ALD with atherosclerotic vascular changes revealed in $79.8 \%$ of people, indicating a significant prevalence of lipid metabolism disorders among people with decompensated alcoholic LC.

\section{Conclusions}

Analyzing clinical records of the pathoanatomical study of the patients with alcoholic liver cirrhosis, it was established that most patients were young and middle aged and died from decompensated LC with the development of multiple organ failure. Bleeding from varicose veins of the esophagus and stomach were the causes of death in $57.5 \%$ of people, $14.8 \%$ of patients died from pancreatic necrosis, $4 \%$ - from HCC. IHD was the concomitant illness in $37.6 \%$ of the patients. More than $70 \%$ of the dead had atherosclerotic lesions of aorta, and one third of the persons had injured coronary vessels. Pancreatic necrosis and cardio-pulmonary failure were the causes of death in most people with stages A and B. GIB, hepatic and hepatic-renal failure, sepsis, and development of HCC were the causes of death in most people with stage C. IHD was the concomitant illness in $37.6 \%$ of the patients.

\section{Conflict of interest}

The author declares no conflict of interest. 


\title{
АНАЛІЗ СМЕРТНОСТІ ХВОРИХ НА АЛКОГОЛЬНИЙ ЦИРОЗ ПЕЧІНКИ
}

\author{
Н.Р. Матковська \\ ДВНЗ “ІВАНО-ФРАНКІВСЬКИЙ НАЦІОНАЛЬНИЙ МЕДИЧНИЙ УНІВЕРСИТЕТ", \\ IBAHO-ФРАНКIBСЬК, УКРАЇНА
}

Вступ. Алкоголь визнають основним фактором ризику несприятливих летальних завершень у всьому світі. В Україні смертність внаслідок алкогольної хвороби печінки (АХП) посіла друге місце в структурі причин смерті від хвороб органів травлення.

Мета. Метою було вивчити особливості причин смерті у осіб з АХП на стадії цирозу печінки (ЦП) на основі аналізу протоколів патологоанатомічного дослідження.

Методи. Проведено аналіз 149 протоколів патологоанатомічного дослідження померлих на алкогольний ЦП на базі патологоанатомічного відділення Івано-Франківської обласної клінічної лікарні за період 2006-2018 pp.

Результати. Більшість осіб були молодого та середнього віку. Летальні випадки були зумовлені декомпенсацією ЦП з розвитком печінкової, печінково-ниркової, серцево-легеневої недостатності, панкреонекрозу, шлунково-кишкових кровотеч, сепсису, гепатоцелюлярної карциноми. У $37,6 \%$ померлих супутньою хворобою була ішемічна хвороба серця, у 10,7\% осіб - гіпертонічна хвороба. У 6\% осіб в анамнезі був перенесений ішемічний інсульт головного мозку. У більшості осіб виявлено атеросклеротичні зміни судин.

Висновки. Надмірне вживання алкоголю $і$, як наслідок, розвиток цирозу печінки можна вважати несприятливим чинником зниження рівня здоров'я населення. У більшості осіб, що померли внаслідок декомпенсації алкогольного виявлено атеросклеротичні ураження судин. Це вказує на значну поширеність порушення ліпідного обміну у осіб з алкогольним цирозом печінки.

КЛЮЧОВІ СЛОВА: алкогольний цироз печінки; причини смерті; ішемічна хвороба серця; атеросклероз.

\section{Інформація про автора}

Матковська Наталія Романівна - доцент кафедри терапії і сімейної медицини післядипломної освіти, канд. мед. наук, ДВНЗ “Івано-Франківський національний медичний університет”, вул. Кропивницького, 16, м. Івано-Франківськ, 76018.

\section{Information about the author}

Natalia R. Matkovska - MD, Ph.D, Assosiate Professor of the Department of Therapy and Family Practice of postgraduate study faculty, Ivano-Frankivsk National Medical University,

16 Kropyvnytskyi str., Ivano-Frankivsk, 76018.

ORCID 0000-0002-9924-2127, e-mail: nmail4you@gmail.com

\section{References}

1. Melnyk PS, Slabkyi HO, Dziuba OM, Chepelevska LA, Kudrenko MV. Annual report on the health status of the population, the sanitary and epidemiological situation and the results of the Ukrainian health care system, 2016. Kyiv: Ministry of health of Ukraine, GA “Ukrainian Institute of Strategic Studies Ministry of Health of Ukraine". 2017;516 [In Ukrainian].

Available at: https://dspace.uzhnu.edu.ua/jspui/ handle/lib/20687

2. Sherstiuk NS, Sokolov AV. Health of Ukraine's population and its impact on the demographic situation. Economics and Society. 2016;5:316-19 [In Ukrainian].

Available at: http://www.economyandsociety. in.ua/journal/5_ukr/57.pdf
3. Parkheta LV. Medical demographic indicators and their impact on the development of voluntary health insurance in Ukraine. Effective economy. 2018;1 [In Ukrainian].

Available at: http://www.economy.nayka.com. $\mathrm{ua} / \mathrm{?op}=1 \& \mathrm{z}=6084$

4. Chepelevska LA, Dziuba OM, Kruchanytsia VV. Regional peculiarities of mortality of the population of Ukraine from fibrosis and cirrhosis of the liver and alcoholic liver disease. Ukraine. The health of the nation. 2016;4/1(41):218-23 [In Ukrainian].

Available at: http://www.irbis-nbuv.gov.ua/cgibin/irbis_nbuv/cgiirbis_64.exe?C21COM=2\&I21DBN $=U J R N \& P 21 D B N=U J R N \& I M A G E \_F I L E \_D O W N L O A D=$ 1\&Image_file_name=PDF/Uzn_2016_4(1)_39.pdf

5. Ruiz-Margáin A, Macías-Rodríguez RU, RíosTorres SL, Román-Calleja BM, Méndez-Guerrero O, 
Rodríguez-Córdova $\mathrm{P}$, et al. Effect of a high-protein, high-fiber diet plus supplementation with branchedchain amino acids on the nutritional status of patients with cirrhosis. Rev Gastroenterol Mex. 2018;83:9.

doi: 10.1016/j.rgmxen.2017.02.005

6. Ali Mokdad A, Lopez AD, Shahraz S, Lozano R, Ali Mokdad H, Stanaway J et. al. Liver cirrhosis mortality in 187 countries between 1980 and 2010: a systematic analysis. BMC Medicine 2014;12:145. doi: 10.1186/s12916-014-0145-y

7. Nilsson E, Anderson H, Sargenti K, Lindgren S, Prytz $\mathrm{H}$. Incidence, clinical presentation and mortality of liver cirrhosis in Southern Sweden: a 10-year populationbased study. Aliment Pharmacol Ther 2016 Jun; 43(12):1330-9.

doi: $10.1111 /$ apt.13635

8. Osodlo HV. Epidemiological and therapeutic aspects of chronic diffuse liver disease in military personnel. Gastroenterology. 2013;4(50):50-6 [In Ukrainian].

Available at: http://www.mif-ua.com/archive/ article/37743

9. Rehm J, Taylor B, Mohapatra S, Irving H, Baliunas D, Patra J, Roerecke M. Alcohol as a risk factor for liver cirrhosis: A systematic review and meta-analysis. Drug and Alcohol Review. 2010 Jul; 29(4):437-45.

doi: 10.1111/j.1465-3362.2009.00153.x

10. Schiavo L, Busetto L, Cesaretti M, Zelber-Sagi Sh, Deutsch L, Iannelli A. Nutritional issues in patients with obesity and cirrhosis. World J Gastroenterol. 2018;24(30):3330-3346.

doi: 10.3748/wjg.v24.i30.3330
11. Chepelevska LA, Krapivina AA. Features of the mortality rate of the population of Ukraine from individual diseases of the digestive system. Ukraine. The health of the nation. 2013; 1 (25): 54-8 [In Ukrainian].

Available at: http://www.irbis-nbuv.gov.ua/cgibin/irbis_nbuv/cgiirbis_64.exe?C21COM=2\&I21DBN $=U J R N \& P 21 D B N=U J R N \& I M A G E \_F I L E \_D O W N L O A D=$ 1\&Image_file_name=PDF/Uzn_2013_1_10.pdf

12. Allen A. M., Kim W. R. Epidemiology and healthcare burden of acute-on-chronic liver failure. Sem Liv Dis 2016 May;36(2):123-6.

doi: $10.1055 / \mathrm{s}-0036-1583201$

13. Fukui $H$, Saito $H$, Ueno $Y$, Uto $H$, Obara $K_{\text {, }}$ Sakaida I, et al. Evidence-based clinical practice guidelines for liver cirrhosis 2015. J Gastroenterol. 2016; 51:629-650.

doi: 10.1007/s00535-016-1216-y

14. Chen H, Zhang Y, Li S, Li N , Chen Y, Zhang B. Direct comparison of five serum biomarkers in early diagnosis of hepatocellular carcinoma. Cancer Manag Res. 2018;10:1947-1958.

doi: 10.2147/CMAR.S167036

15. Fialla $A D$, Israelsen $M$, Hamberg $O$, Krag $A$, Gluud LL. Nutritional therapy in cirrhosis or alcoholic hepatitis: a systematic review and meta-analysis. Liver Int. 2015; 35:2072-2078.

doi: $10.1111 /$ liv.12798

16. Garbuzenko D, Arefyev N, Kazachkov E. Antiangiogenic therapy for portal hypertension in liver cirrhosis: Current progress and perspectives. World J Gastroenterol. 2018;24(33):3738-3748.

doi: 10.3748/wjg.v24.i33.3738

Received 19 February 2019; revised 18 March 2019; accepted 12 April 2019

This is an open access article distributed under the Creative Commons Attribution License, which permits unrestricted use, distribution, and reproduction in any medium, provided the original work is properly cited. 